дослідженні було використано 15 райдужних форелей необробленого контролю $i$ 15 вакцинованих форелей. Через два місячі після імунізації були відібрані зразки райдужної форелі. Риба була спіймана та убита через 61 день після вакииначії ( $n=15$ у кожній групі). Зябра видалені на місці. Органи промивали від крові холодним буфером для виділення $і$ гомогенізували, використовуючи скляний гомогенізатор Н500 з рухомим товкачем, зануреним в баню з крижаною водою, з отриманням гомогенної речовини у співвідноменні 1: 9 (вага / об'єм). Буфер для виділення характеризувався $100 \mathrm{mM} \mathrm{Tpic-HCl;} \mathrm{pH} \mathrm{7,2} \mathrm{доводили} \mathrm{за} \mathrm{допомогою} \mathrm{HCl}$. Гомогенати иінтрифугували при $3000 \mathrm{~g}$ протягом 15 хв при $4{ }^{\circ} \mathrm{C}$. Після иеентрифугування супернатант збирали $i$ заморожували при $-20{ }^{\circ} \mathrm{C}$ до аналізу. Вміст білку визначали за методом Бредфорда (1976) з використанням бичачого альбуміну сироватки в якості стандарту. Поглинання реєстрували при 595 нм. Всі ферментативні аналізи проводили при $22 \pm 0,5{ }^{\circ} \mathrm{C}$ з використанням спектрофотометра Specol 11 (Carl Zeiss Jena, Німеччина) в двох повторностях. Ферментативні реакиї запускали додаванням тканинного супернатанта.

Наші результати показали, щз імунізація не змінює жабри райдужної форелі. Параметри окисного стресу, досліджені в гомогенаті жаьер, тобто перекисне окислення ліпідів, щуо вимірюється за кількістю речовин, що реагують з 2тіобарбітуровою кислотою, а також альдегідних (збільшилося на 18,9 \%) $і$ кетонових похідних окислювально модифікованих білків (зменшилося на 6,5 \%), змінилися незначно $(p>0,05)$ в жабрах вакцинованих риб. Таким чином, імунізація вакциною проти Үегsinia не змінюе вмісту біомаркерів окисного стресу в порівнянні з необробленим контролем на другий місящь після імунізаиії. Наші результати підтверджують, щзо вакиина проти Y. ruckeri не робить шкідливого впливу на стан і метаболізм в жабрах риб. Зміни вмісту біомаркерів окисного стресу доводять, щзо вакиина проти Y. ruckeri не має негативних ефектів.

Ключові слова: Yersinia ruckeri, райдужна форель (Oncorhynchus mykiss Walbaum), жабра, пероральна вакциначія, речовини, що реагують 3 2тіобарбітурової кислотою, альдегідні і кетонові похідні окислювально модифікованих білків.

UDC636.1.083.38:591.1

DOI 10.32900/2312-8402-2020-124-35-46

\title{
EXERCISE-INDUCED CHANGES IN THE LEVEL OF TOTAL PROTEIN AND ITS FRACTIONS IN THE BLOOD OF HORSES INVOLVED IN RECREATIONAL HORSEBACK RIDING
}

\author{
Tkachenko H., Doctor of Biological Sciences
}

Kurhaluk N., Doctor of Biological Sciences

Institute of Biology and Earth Sciences, Pomeranian University in Słupsk

Tkachova I., Doctor of Agricultural Sciences

The Institute of Animal Science NAAS, Kharkiv, Ukraine

The aim of the current study was to do the analysis of the total protein and its fraction in the blood samples of horses, which are involved in recreational horseback riding in the Pomeranian region (Pomeranian Voivodship, northern Poland).

Thirteen healthy adult horses from the Pomeranian region in Poland (Strzelinko

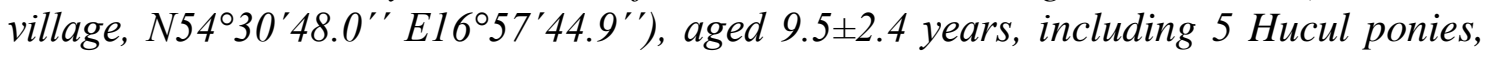


2 Thoroughbred horses, 2 Anglo-Arabian horses, and 4 horses of unknown breed, were used in the current study. Training started at 10:00 AM, lasted 1 hour, and consisted of a ride of cross country by the walking $(5 \mathrm{~min})$, the trotting $(15 \mathrm{~min})$, the walking $(10$ min), the trotting (10 min), the walking (5 $\mathrm{min})$, the galloping $(5 \mathrm{~min})$, and the walking (10 min). Blood samples were taken from the jugular veins of the animals in the morning time, 90 minutes after feeding, while the horses were in the stables (between 8:30 and 10 AM), and immediately after the exercise session (between 11:00 AM and 2:00 PM). To obtain serum, the blood was collected in plain tubes without anticoagulants. Blood was stored in tubes with $K_{3}$-EDTA and held on ice until centrifugation at 3,000g for 15 minutes. The plasma was removed. The total protein and its fractions were measured at $+23^{\circ} \mathrm{C}$ by the biuret method with the use of commercially available reagents and a compact semi-automated analyzer RX Monza (Randox Laboratories LTD., UK) according to the procedures described by the manufacturer. The biuret method is the most widely used colorimetric method for the determination of the total protein concentration in serum because of its simplicity, precision, and accuracy. The absorbance of each sample was measured in duplicate. Results are expressed as mean \pm S.E.M. All variables were tested for normal distribution using the Kholmogorov-Smirnov test $(p>0.05)$. To find significant differences (significance level, $p<0.05$ ) between at the rest and after exercise, the Wilconson signed-rank test was applied to the data. All statistical analyses were performed using STATISTICA 8.0 software (StatSoft, Krakow, Poland).

The total protein level in the blood of horses exhibited a non-significant increase (by $7.1 \%, p>0.05$ ) immediately after exercise as compared to the resting period. Also, the albumin and globulin levels in the blood of horses were non-significantly increased by $5.9 \%(p>0.05)$ and $8.1 \%(p>0.05)$ after the training sessions. There were no significant differences in serum albumin/globulin ratio between the resting period and after exercise (0.997 \pm 0.09 vs. $0.977 \pm 0.08)$.

The results of our current study showed that exercise has a statistically nonsignificant effect on the total proteins and their fractions in equine serum. The fractions and the $A / G$ ratio were within the range of values obtained in horses in other studies.

Thus, it was found that total protein and its fractions were increased in horses after training, and this increase was insignificant. This increase has a direct correlation with exercise. In this paper, it is shown that training can change the physiology and affect the biochemistry of hematobiochemical blood parameters in horses subjected to physical exertion.

Keywords: horses, recreational horseback riding, Pomeranian region (Poland), training session, total protein, protein fractions, albumins, globulins, albumin to globulin ratio (AGR)

The performance of training or exercise is a major physiologic challenge, a disturbance to homeostasis that invokes an integrative response from multiple organ systems. The response to exercise involves endocrine and neuroendocrine signaling associated with the short-term and adaptive control of many systems [28]. Adaptation of nervous, cardiovascular, endocrine, and respiratory systems depends on the intensity, duration, and type of physical exercise [39]. Equine metabolic variations have to adapt to organism requirements. The goal of changes in catabolic reactions is to maintain optimal ATP concentration and high $\mathrm{O}_{2}$ consumption, as well as augmented biochemical processes, to face the accumulation of resulting metabolites [23].

Hines and co-workers (1996) revealed that exercise has dual effects on the immune system. Suppressive effects, such as a decline in the ratio of CD4+ to CD8+ cells, diminished lymphocyte function, and a decline in the number and cytolytic activity of 
natural killer cells have been observed in response to brief high-intensity exercise, prolonged exhaustive exercise, and overtraining. In contrast, moderate training generally has beneficial effects on host defense mechanisms [22]. Single bouts of aerobic and anaerobic exercise can induce an acute state of oxidative stress. This is indicated by an increased presence of oxidized molecules in a variety of tissues. Exercise mode, intensity, and duration, as well as the subject population, tested, all can impact the extent of oxidation [18].

The results obtained by Scoppetta and co-workers (2012) indicate that prolonged physical exercise affects plasma proteins involved in pathways related to inflammation, coagulation, immune modulation, oxidant/antioxidant activity, and cellular and vascular damage, with consequent effects on whole horse metabolism [39]. In the study of Scoppetta and co-workers (2012), a proteomic approach to investigate the changes in plasma protein levels in horses as a result of prolonged physical exercise was used. Unlike observations limited to a single protein, proteomics provided a holistic view of the deregulated molecular functions associated with physical stress. Various proteins involved in different pathways related to physical stress response showed significant quantitative changes, suggesting novel scenarios on this highly investigated physiological condition [39].

Albumin, the most abundant protein in plasma, is a monomeric multi-domain macromolecule, representing the main determinant of plasma oncotic pressure and the main modulator of fluid distribution between body compartments [15]. Albumin represents the main carrier for fatty acids, affects the pharmacokinetics of many drugs, provides the metabolic modification of some ligands, renders potential toxins harmless, accounts for most of the antioxidant capacity of human plasma, and displays (pseudo-) enzymatic properties $[14,32]$. Albumin is widely used clinically to treat several diseases, including hypovolemia, shock, burns, surgical blood loss, trauma, hemorrhage, cardiopulmonary bypass, acute respiratory distress syndrome, hemodialysis, acute liver failure, chronic liver disease, nutrition support, resuscitation, and hypoalbuminemia [2, $16,20,46,47]$.

Serum albumin and globulin, the two major components of serum proteins, have been confirmed to be involved in the systemic inflammatory process. Serum albumin, one of the biochemical tests, indicates nutritional status and relates to chronic inflammation of organisms. Moreover, increased levels of globulin could serve as a marker of chronic inflammation response and reflect a cumulative exposure of various proinflammatory cytokines [19]. The other major component of serum protein, globulin, is the primary cortisol binding protein, playing an important role in immunity and inflammation [21, 29]. Recently, albumin to globulin ratio (AGR), calculated as AGR = albu$\mathrm{min} /$ globulin, is widely used as a prognostic indicator in diverse human cancers [27] and on survival in patients with heart failure [26].

Thus, the aim of the current study was the analysis of the total protein and its fraction in the blood of horses involved in recreational horseback riding in the Pomeranian region (Pomeranian Voivodship, northern Poland).

Materials and methods. Horses. Thirteen healthy adult horses from the Pomer-

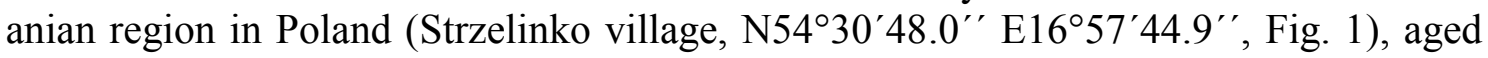
9.5 \pm 2.4 years, including 5 Hucul ponies, 2 Thoroughbred horses, 2 Anglo-Arabian horses, and 4 horses of unknown breed, were used in the current study. All horses participated in recreational horseback riding and were subjected to the resembling type of management. Horses were housed in individual boxes under natural spring photoperiod (sunrise at 06:00 h, sunset at 19:00 h), with feeding (hay and oat) provided twice a day, at 08.00 and $18.00 \mathrm{~h}$, and water available ad libitum. All horses were thoroughly exam- 
ined clinically and screened for hematological, biochemical, and vital parameters, which were within reference ranges. The females were non-pregnant.

Training session. Training started at 10:00 AM, lasted 1 hour, and consisted of a ride of cross country by the walking $(5 \mathrm{~min})$, the trotting $(15 \mathrm{~min})$, the walking $(10 \mathrm{~min})$, the trotting $(10 \mathrm{~min})$, the walking $(5 \mathrm{~min})$, the galloping $(5 \mathrm{~min})$, and the walking (10 min) (Fig. 2).
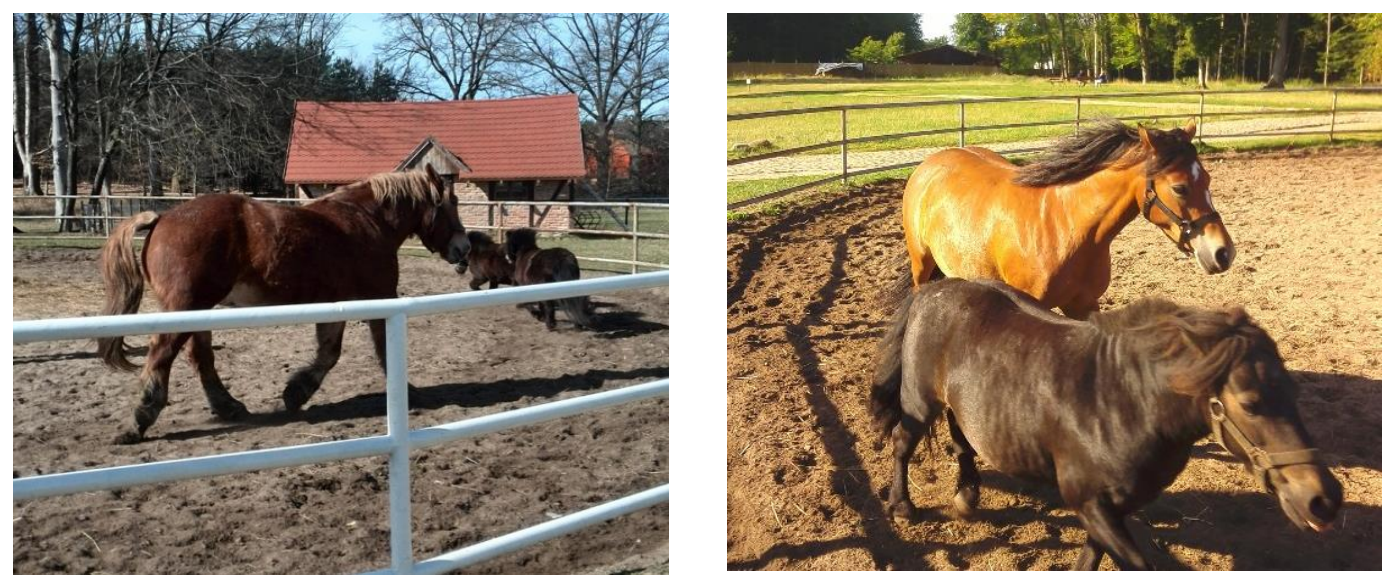

Fig. 2. The training sessions involved walking, trotting, and galloping

Blood samples. Blood was drawn from the jugular veins of the animals in the morning, 90 minutes after feeding, while the horses were in the stables (between 8:30 and 10 AM), and immediately after the exercise session (between 11:00 AM and 2:00 PM). To obtain serum, the blood was collected into plain tubes without anticoagulants. Blood samples were stored in tubes with $\mathrm{K}_{3}$-EDTA and held on ice until centrifugation at 3,000g for 15 minutes. The plasma was removed.

The total protein and its fractions. The total protein and its fractions were measured at $+23^{\circ} \mathrm{C}$ by the biuret method with the use of commercially available reagents and a compact semi-automated analyzer RX Monza (Randox Laboratories Ltd., UK) according to the procedures described by the manufacturer. The biuret method is the most widely used colorimetric method for the determination of the total protein concentration in serum because of its simplicity, precision, and accuracy [24]. The absorbance of each sample was measured in duplicate.

Statistical analysis. Results are expressed as mean \pm S.E.M. All variables were tested for normal distribution using the Kolmogorov-Smirnov test $(p>0.05)$. To find significant differences (significance level, $\mathrm{p}<0.05$ ) between at the rest and after exercise, the Wilcoxon signed-rank test was applied to the data [48]. All statistical analyses were performed using STATISTICA 8.0 software (StatSoft, Krakow, Poland).

Results and discussion. Physical effort influences many parameters in the horse blood and since training should lead to more efficient energy metabolism, it seems advisable to determine hematological and biochemical parameters during the training session in horses [3-8, 17, 25, 33-37, 42-45]. Therefore, this study aimed to determine the exercise-induced variations on total protein and its fractions in horses involved in recreational horseback riding in the Pomeranian region. The total protein and its fractions during the training session were measured through analysis of the level of albumins and globulins, as well as serum albumin/globulin ratio (A/G ratio) and shown in Fig. 3. 


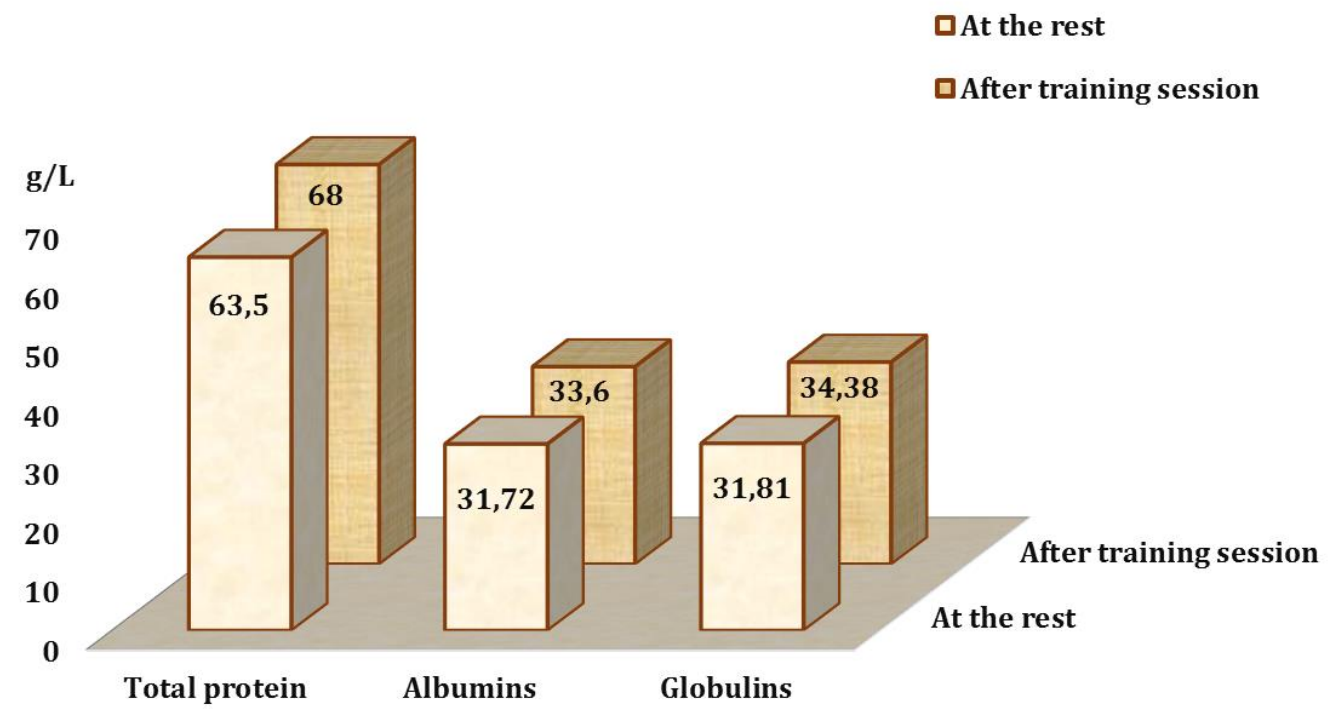

Fig. 3. The exercise-induced variations on total protein and its fractions (albumins and globulins) in horses involved in recreational horseback riding in the Pomeranian region.

Values are expressed as mean.

The total protein level in the blood of horses exhibited a non-significant increase (by $7.1 \%, \mathrm{p}>0.05$ ) immediately after exercise as compared to the resting period. Also, the albumin and globulin levels in the blood of horses were non-significantly increased by $5.9 \%(\mathrm{p}>0.05)$ and $8.1 \%(\mathrm{p}>0.05)$ after the training sessions. There were no significant differences in serum albumin/globulin ratio between the resting period and after exercise $(0.997 \pm 0.09$ vs. $0.977 \pm 0.08)$ (Fig. 3$)$.

The results of our current study showed that exercise has a statistically nonsignificant effect on the total proteins and their fractions in equine serum. The fractions and the $\mathrm{A} / \mathrm{G}$ ratio were within the range of values obtained in horses in other studies. Darden and co-workers (2019), using both the hematology and the biochemistry of the blood hematobiochemical parameters in horses, evaluated the effect of plasmapheresis on clinical, hematological, and biochemical parameters after exercise. A plasmapheresis session was realized on six jumping horses (plasmapheresis group) that underwent three consecutive days of physical graded exercise. Plasmapheresis induced a very significant decrease $(\mathrm{P}<0.001)$ of albumin and globulin levels and of total protein, which was reestablished 24 hours later [15].

Competitive acute running exercise has been shown to act on various hematologic variables potentially influential in determining the degree of blood viscosity in 10 Thoroughbred horses [13]. Following the completion of sprints over a distance of 1.25 miles, mean percent $( \pm \mathrm{SD})$ increases in packed cell volume (PCV) $(38.3 \pm 12.9 \%)$, count of red blood cells (RBC) $(47.8 \pm 15.3 \%)$, and rouleaux index $(232.7 \pm 176.8 \%)$ were recognized. Simultaneous increases in total plasma protein $(28.3 \pm 5.31 \%)$, serum albumin $(26.7 \pm 6.80 \%)$, $\alpha 1$-globulin $(60.0 \pm 49.0 \%), \alpha_{2}$-globulin $(25.5 \pm 27.9 \%), \beta 1$-globulin $(46.7 \pm 21.1 \%), \beta_{2}$-globulin (35.0 $\left.\pm 50.6 \%\right), \gamma_{1}$ - and 2-globulins $(38.7 \pm 29.6 \%)$, and plasma fibrinogen $(12.5 \pm 10.4 \%)$ concentrations increased simultaneously. Horses also had

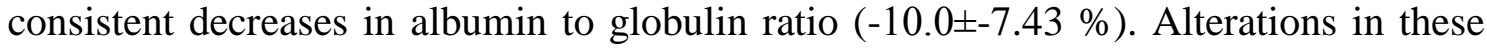
hematologic values after acute running exercise in Thoroughbred horses accompanied 
increases in serum $(69.3 \pm 39.7 \%)$, plasma $(39.7 \pm 11.9 \%)$, and blood $(134.7 \pm 55.3 \%)$ viscosity [17].

Previous studies demonstrate that the values of the total protein obtained in healthy show jumping horses of different age, sex, and breed range at the rest ranged from 62.5 to $75.0 \mathrm{~g} / \mathrm{L}$. According to a study obtained by Szarska (2003), showjumping horses have a non-significant higher content of total protein measured at rest $(67.1 \mathrm{~g} / \mathrm{L})$ compared to racehorses (60.2-64.2 g/L) [41]. In the study of Burlikowska and coworkers (2015), significantly higher levels of total protein and albumin were determined in the blood of sport horses compared to recreationally used horses [10].

These findings demonstrate that serum protein fractions can be influenced by the training sessions. Total protein and its fractions were non-significant increased. Exercise could influence the $\mathrm{A} / \mathrm{G}$ ratio. There is a discrepancy in the veterinary literature regarding values for the physiological $\mathrm{A} / \mathrm{G}$ ratio in horses $[11,30]$. Riond and co-workers (2009) have established reference intervals for serum protein concentrations in adult horses using agarose gel electrophoresis and to assess differences between warmblooded and heavy draught horses. No significant difference was found between warmblooded and heavy draught horses and so combined reference intervals (2.5-97.5\%) were calculated for total protein (51.0-72.0 g/L), albumin (29.6-38.5 g/L), $\alpha_{1}$-globulin (1.9-3.1 g/L), $\alpha_{2}$-globulin (5.3-8.7 g/L), $\beta_{1}$-globulin $(2.8-7.3 \mathrm{~g} / \mathrm{L}), \beta_{2}$-globulin (2.2$6.0 \mathrm{~g} / \mathrm{L})$, and $\gamma$-globulin $(5.8-12.7 \mathrm{~g} / \mathrm{L})$ concentrations, and albumin/globulin ratio (0.931.65) [37].

The results found for ponies agree with those previously reported for in fit horses competing in an $\mathrm{FEI}^{* * *} 120 \mathrm{~km}$ endurance race as well as at rest and after the crosscountry jumping phase of a horse trial competition [1, 40]. Packed cell volume and plasma total protein (TP), serum albumin (Alb) and globulin (Glb), and plasma ionized calcium (PCa) concentrations, blood viscosity (BV), and plasma viscosity (PV) were measured in 42 horses at rest and after the cross-country jumping phase of a horse trial competition by Sommardahl and co-workers (1994). The PCV, TP, Alb, and Glb values increased in horses after exercise. The PCA concentration decreased in horses after exercise. Mean BV and PV in the 42 horses at rest and after exercise was fitted to an asymptotic function. Significant correlation at all shear rates was seen between BV at rest and PCV, TP, Alb, Glb, and PCa values at rest; and between BV after exercise and PCV, TP, Alb, Glb, and PCa values after exercise. A significant correlation was not seen between PV at rest and TP, Alb, Glb, and PCa at rest, or between PV after exercise and TP, Alb, Glb, and PCa concentrations after exercise at any shear rate [40].

Aguilera-Tejero and co-workers (2000) have described acid-base and electrolytes changes in fit horses competing in an FEI*** $120 \mathrm{~km}$ endurance race and to compare the traditional $v s$. strong ion approaches. Thirty horses were initially enrolled in the study. Venous blood samples were obtained before the race $(\mathrm{n}=25)$, at the second $(\mathrm{n}=$ $29 ; 65.4 \mathrm{~km})$ and third vet-gates $(\mathrm{n}=23,97.4 \mathrm{~km})$ and upon race completion $(\mathrm{n}=17)$. Blood gas analysis was performed to determine $\mathrm{pH}, \mathrm{PCO}_{2}, \mathrm{PO}_{2}, \mathrm{Na}^{+}, \mathrm{K}^{+}$, and $\mathrm{iCa}^{2+}$, and calculate $\mathrm{HCO}^{3-}$, base excess, and $\mathrm{tCO}_{2}$. Packed cell volume and total protein, globulin, albumin, lactate, phosphate, glucose, and creatinine concentrations, as well as muscle enzyme activities, were also determined. Calculated variables included strong ion difference, strong ion gap, and nonvolatile buffer concentration. A longitudinal linear model using the generalized estimating equation methodology was used for statistical analysis. Mild but significant increases in $\mathrm{PCO}_{2}$, strong ion difference, lactate, plasma protein, globulins, and nonvolatile buffer concentration, as well as a decrease in potassium concentrations, were observed from the second vet-gate to race finish when compared to prerace values. Using the strong ion approach, $67 \%$ of samples showed acid- 
base disturbances vs. $70 \%$ when using the traditional method, but their interpretations only matched in $24 \%$ of measurements [1].

The findings of Arfuso and co-workers (2016) are related to dynamic physiological adaptations to exercise that allow re-establishment of the homeostatic equilibrium of the organism. These authors evaluated the effect of exercise on platelet aggregation, albumin, and non-esterified fatty acids' values in ten clinically healthy and regularly trained Thoroughbred horses. The correlation among these parameters was evaluated. All horses were subjected to two simulated races. Blood samples were collected by jugular venipuncture before and after the first simulated race, every 7 days at rest condition for a month, and before and after the second simulated race to assess platelet aggregation, albumin, and non-esterified fatty acids levels. One-way analysis of variance showed a significant effect of exercise on platelet aggregation, albumin, and nonesterified fatty acids' values. A negative correlation between platelet aggregation and albumin or non-esterified fatty acids' values, and a positive correlation between albumin and non-esterified fatty acids' values, were found both after the first simulated race and the before the second simulated race [9].

In the study of Scoppetta and co-workers (2012), protein modifications in horse plasma induced by prolonged, aerobic physical exercise were investigated by using a proteomic approach. Thirty-eight protein spots, associated with expression products of 13 genes, showed significant quantitative changes; spots identified as membrane $\mathrm{Cu}$ amine oxidase, $\alpha-1$ antitrypsin, $\alpha-1$ antitrypsin-related protein, ceruloplasmin, $\alpha_{2}-$ macroglobulin, and complement factor $\mathrm{C} 4$ were augmented in relative abundance after the race, while haptoglobin $\beta$ chain, apolipoprotein A-I, transthyretin, retinol-binding protein 4 , fibrinogen $\gamma$ chain, complement factor B and albumin fragments were reduced [39].

The serum protein gram, identifying and quantifying the acute-phase proteins (APPs) of horses used in show jumping activity with obstacles of a meter in height were evaluated by CarvalhoFilho and co-workers (2020). The serum of 10 horses was evaluated in a competition for beginners. The material was collected at rest (T0), immediately after exercise (T1), 30 minutes after the effort (T2), 1 hour after the effort (T3), and 24 hours after the effort. Eight APPs were identified: $\alpha 2$-macroglobulin ( $\alpha 2$-macro), ceruloplasmin (Cp), transferrin (Trf), albumin (Alb), $\alpha 1$-antitrypsin ( $\alpha 1$-ATP), haptoglobin (Hp), acid glycoprotein (AGP), and apolipoprotein A1 (Apo A1). There was a difference in Cp, AGP, and Apo A1 between moments [12].

It is well demonstrated that albumin levels are influenced by exercise [31]. Serum albumin concentrations were determined from over five hundred Thoroughbred horses of various ages and physiological states. A significant difference $(p<0.01)$ between the value for the two-year-old and yearling is recorded. It is suggested that this may be the result of a dietary deficiency during the period the two-year-old is required to perform the strenuous exercise as well as continue its normal growth.

Conclusions. The total protein and its fractions were raised in horses after the training session, this increase being non-significants. This increase has a direct correlation with exercise. The present work has demonstrated that the training session can modify the physiology and affect the biochemistry of the blood hematobiochemical parameters in horses subjected to physical exercise.

\section{References}

1. Aguilera-Tejero, E., Estepa, J.C., López, I., Bas, S., Mayer-Valor, R., \& Rodríguez, M. (2000). Quantitative analysis of acid-base balance in show jumpers before and after exercise. Res. Vet. Sci., 68(2), 103-108. 
2. Alexander, M. R., Alexander, B., Mustion, A. L., Spector, R., \& Wright, C. B. (1982). Therapeutic use of albumin : 2. JAMA, 247(6), 831-833.

3. Andriichuk, A., \& Tkachenko, H. (2017). Effect of gender and exercise on haematological and biochemical parameters in Holsteiner horses. J. Anim. Physiol. Anim. Nutr. (Berl)., 101(5), e404-e413.

4. Andriichuk, A., Tkachenko, H., \& Kurhaluk, N. (2014). Gender differences of oxidative stress biomarkers and erythrocyte damage in well-trained horses during exercises. Journal of Equine Veterinary Science, 34, 978-985.

5. Andriichuk, A., Tkachenko, H., \& Tkachova, I. (2015). Hematological alterations and osmotic resistance of erythrocytes in endurance horses during $32 \mathrm{~km}$ races. StupskiePraceBiologiczne, 12, 5-20.

6. Andriichuk, A., Tkachenko, H., \& Tkachova, I. (2015). The oxidative stress and antioxidant defense in the blood of the jumping horses during exercise. Stupskie Prace Biologiczne, 12, 21-42.

7. Andriichuk, A., Tkachenko, H., \& Tkachova, I. (2016). Oxidative Stress Biomarkers and Erythrocytes Hemolysis in Well-Trained Equine Athletes Before and After Exercise. Journal of Equine Veterinary Science, 36, 32-43.

8. Andriichuk, A.V., Tkachenko, H.M., \& Tkachova, I.V. (2016). Hematological changes and resistance of erythrocytes of Crimean horses in response to $32 \mathrm{~km}$ races. Agric. Sci. Pract., 3(1), 66-72.

9. Arfuso, F., Giannetto, C., Giudice, E., Fazio, F., \& Piccione, G. (2016). Dynamic modulation of platelet aggregation, albumin and nonesterified fatty acids during physical exercise in Thoroughbred horses. Res. Vet. Sci., 104, 86-91.

10. Burlikowska, K., Bogusławska-Tryk, M., Szymeczko, R., \& Piotrowska, A. (2015). Haematological and biochemical blood parameters in horses used for sport and recreation. Journal of Central European Agriculture, 16(4), 370-382.

11. Carapeto, V., Barrera, M., CintaMañe, R., \& Zaragoza, M.C. (2006). Serum $\alpha$-globulin fraction in horses is related to changes in the acute phase proteins. J. Equine Vet. Sci., 26, 120-127.

12. CarvalhoFilho, W. P., Girardi, F. M., Souto, P. C., Orozco, A. M. O., de Oliveira, T., Dornelas, L. R. S. M., Jimenez, A. K. A., \& Fonseca, L. A. D. (2020). Profile of Acute-Phase Proteins of Horses Submitted to Low-Level Show Jumping Classes. J. Equine Vet. Sci., 91, 103105.

13. Coyne, C. P., Carlson, G. P., Spensley, M. S., \& Smith, J. (1990). Preliminary investigation of alterations in blood viscosity, cellular composition, and electrophoresis plasma protein fraction profile after competitive racing activity in Thoroughbred horses. Am. J. Vet. Res., 51(12), 1956-1963.

14. Curry, S. (2002). Beyond expansion: structural studies on the transport roles of human serum albumin. Vox. Sang, 83 (Suppl. 1), 315-319.

15. Daden, R., Zarhouni, F. Z., Chakir, J., Piro, M., Achaâban, M. R., Ouassat, M., El \& Allali, K. (2019). Plasmapheresis Effect on Hematological and Biochemical Parameters in Athletic Horses Subjected to Exercise. J. Equine Vet. Sci., (81), 102785.

16. Fanali, G., di Masi, A., Trezza, V., Marino, M., Fasano, M., \& Ascenzi, P. (2012). Human serum albumin: from bench to bedside. Mol. Aspects Med., 33(3), 209290.

17. Fazio, F., Assenza, A., Tosto, F., Casella, S., Piccione, G., \& Caola, G. (2011). Training and haematochemical profile in Thoroughbreds and Standardbreds : A longitudinal study. Livestock Science, 141, 221-226. 
18. Fisher-Wellman, K., \& Bloomer, R. J. (2009). Acute exercise and oxidative stress: a 30 year history. Dyn. Med., 8, 1 .

19. Gabay, C., \& Kushner, I. (1999). Acute-phase proteins and other systemic responses to inflammation. N. Engl. J. Med., 340(6), 448-454.

20. Hastings, G. E., \& Wolf, P. G. (1992). The therapeutic use of albumin. Arch. Fam. Med., 1(2), 281-287.

21. Hill, L. A., Bodnar, T. S., Weinberg, J., \& Hammond, G. L. (2016). Corticosteroid-binding globulin is a biomarker of inflammation onset and severity in female rats. J. Endocrinol., 230(2), 215-225.

22. Hines, M.T., Schott, H. C., Bayly, W. M., \& Leroux, A. J. (1996). Exercise and immunity: a review with emphasis on the horse. J. Vet. Intern. Med., 10(5), 280289.

23. Joyner, M. J., \& Coyle, E. F. (2008). Endurance exercise performance : the physiology of champions. J. Physiol., 586(1), 35-44.

24. Kaneko, J. J. Harvey J. W., \& Bruss M. L., editors. (1997). Serum proteins and the dysproteinemias. Clinical Biochemistry of Domestic Animals. $5^{\text {th }}$ ed., San Diego, California : Academic Press; p. 117-137.

25. Kirschvink, N., de Moffarts, B., \& Lekeux, P. (2008). The oxidant/antioxidant equilibrium in horses. Vet. J., 177(2), 178-191.

26. Li, K., Fu, W., Bo, Y., \& Zhu, Y. (2018). Effect of albumin-globulin score and albumin to globulin ratio on survival in patients with heart failure: a retrospective cohort study in China. BMJ Open, 8(7), e022960.

27. Lv, G. Y., An, L., Sun, X. D., Hu, Y. L., \& Sun, D. W. (2018). Pretreatment albumin to globulin ratio can serve as a prognostic marker in human cancers: a meta-analysis. Clin. Chim. Acta, 476, 81-91.

28. McKeever, K. H. (2011). Endocrine alterations in the equine athlete: an update. Vet. Clin. North Am. Equine Pract., 27(1), 197-218.

29. Meyer, E. J., Nenke, M. A., Rankin, W., Lewis, J. G., \& Torpy, D. J. (2016). Corticosteroid-Binding Globulin: A Review of Basic and Clinical Advances. Horm. Metab. Res., 48(6), 359-371.

30. Mitruka, B. M., Rawnsley, H. M. (1977). Clinical Biochemical and Hematological Reference Values in Normal Experimental Animals. New York, Masson; Publishing USA. Clinical biochemistry; p. 117-245.

31. Mullen, P. A. (1970). Variations in the Albumin Content of Blood Serum in Thoroughbred Horses. Equine Veterinary Journal, 2(3), 118-120.

32. Peters, T. Jr. (Ed.) (1996). All about Albumin: Biochemistry, Genetics and Medical Applications, Academic Press, San Diego and London.

33. Piccione, G., Casella, S., Giannetto, C., Messina, V., Monteverde, V., Caola, G., \& Guttadauro, S. (2010). Haematological and haematochemical responses to training and competition in Standardbred horses. Comp. Clin. Pathol., 19, 95-101.

34. Piccione, G., Casella, S., Giannetto, C., Monteverde, V., \& Ferrantelli, V. (2009). Exercise-induced modifications on haematochemical and electrophoretic parameters during 1600 and 2000 meters trot races in Standardbred horses. J. Appl. Anim. Res., 35, 131-135.

35. Piccione, G., Casella, S., Monteverde, V., Giannetto, V., \& Caola, G. (2008). Haematological modifications during official 1600 and 2000 meters trot races in Standardbred horses. Acta Vet. (Beogr)., 58(4), 325-332.

36. Piccione, G., Giannetoo, C., Fazio, M., Mauro, S., \& Caola, G. (2007). Haematological response to different workload in jumper horses. Bulgarian Journal of Veterinary Medicine, 10 (4), 21-28. 
37. Piccione, G., Vazzana, I., Giannetto, C., Gianesella, M., \& Ferrantelli, V. (2008). Modification of some haematological and haematochemical parameters in horse during long distance rides. Res. J. Vet. Sci., 1(1), 37-43.

38. Riond, B., Wenger-Riggenbach, B., Hofmann-Lehmann, R., \& Lutz, H. (2009). Serum protein concentrations from clinically healthy horses determined by agarose gel electrophoresis. Vet. Clin. Pathol., 38(1), 73-77.

39. Scoppetta, F., Tartaglia, M., Renzone, G., Avellini, L., Gaiti, A., Scaloni, A., \& Chiaradia, E. (2012). Plasma protein changes in horse after prolonged physical exercise: a proteomic study. J. Proteomics, 75(14),4494-4504.

40. Sommardahl, C. S., Andrews, F. M., Saxton, A. M., Geiser, D. R., \& Maykuth, P. L. (1994). Alterations in blood viscosity in horses competing in cross country jumping. Am. J. Vet. Res., 55(3), 389-394.

41. Szarska, E. (2003). Investigations of blood parameters for evaluation of health status and training effects in race and sport horses. AR Wrocław, Poland, $115 \mathrm{p}$.

42. Tkachenko, H., Andriichuk, A., \& Tkachova, I. (2018). Hematological profile of English half-breed horses reared Pomeranian region (northern Poland). Scientific and technical bulletin of Institute of Animal Husbandry, National Academy of Agrarian Sciences of Ukraine, Kharkiv, 119: 22-33.

43. Tkachenko, H., Kurhaluk, N., \& Tkachova, I. (2020). Exercise-induced alterations of the oxidative stress biomarkers in erythrocytes of ponies involved in recreational horseback riding. The Scientific and Technical Bulletin of the Institute of Animal Science NAAS of Ukraine, 123, 39-48.

44. Tkachenko, H., Pażontka-Lipiński, P., \& Witaszek, P. (2016). Seasonal alterations in exercise-induced oxidative stress of horses involved in recreational horseback ride. In: Globalisation and regional environment protection. Technique, technology, ecology. Eds T. Noch, W. Mikołajczewska, A. Wesołowska. Gdańsk, Gdańsk High School Publ., p. 193-212.

45. Tkachenko, H., Witaszek, M., \& Pażontka-Lipiński, P. (2018). Exerciseinduced biochemical alterations in the blood of horses involved in recreational horseback riding in Pomeranian region (northern Poland). Journal of Ecology and Protection of the Coastline (Baltic Coastal Zone), 22, 91-108.

46. Tullis, J. L. (1977). Albumin. 1. Background and use. JAMA, 237(4), 355360.

47. Tullis, J. L. (1977). Albumin. 2. Guidelines for clinical use. JAMA, 237(5), $460-463$.

48. Zar, J. H. (1999). Biostatistical Analysis. $4^{\text {th }}$ ed., Prentice Hall Inc., New Jersey.

ИЗМЕНЕНИЯ УРОВНЯ ОБЩЕГО БЕЛКА И ЕГО ФРАКЦИЙ В КРОВИ ЛОШАДЕЙ, ИСПОЛЬЗУЮЩИХСЯ В РЕКРЕАЦИОННОЙ ВЕРХОВОЙ ЕЗДЕ, ПОД ВОЗДЕЙСТВИЕМ ФИЗИЧЕСКОЙ НАГРУЗКИ

Ткаченко Г. М., Кургалюк Н. М., Институт биологии и наук о Земле Поморского университета в Слупске, Польша

Ткачева И. В., Институт животноводства НААН

Целью настоящего исследования было проведение анализа общего белка и его фракции в образиах крови лошадей, использующихся в рекреачионной верховой езде в Поморском регионе (Поморское воеводство, Северная Польша). В исследовании использовались тринадиать здоровых взрослых лошадей из Поморского региона Польши (деревня Стшелинко, N54³048,0 E165744,9) в возрасте

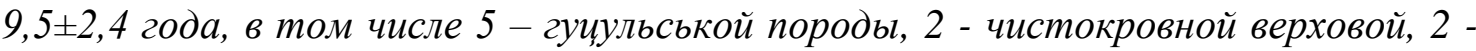


англо-арабской и 4 лошади неопределенной породы. Тренировка начиналась в 10:00 утра, длилась 1 час и состояла из езды по пересеченной местности шагом (5 мин), рысью (15 мин), шагом (10 мин), рысью (10 мин), шагом (5 мин), галопом (5 мин) и шагом (10 мин). Образцы крови брали из яремных вен животных в утреннее время, через 90 минут после кормления, когда лошади находились в конюшне (между 8:30 и 10 часами утра), и сразу после тренировки (между 11:00 и 2:00 вечера). Для получения сыворотки кровь собирали в простые пробирки без антикоагулянтов. Кровь хранили в пробирках с КЗ-ЭДТА и выдерживали на льду до иентрифугирования при $3000 \mathrm{~g}$ в течение 15 минут. Плазма была удалена. Общий белок и его фракиии измеряли при температуре $+23{ }^{\circ} \mathrm{C}$ биуретовым методом с использованием коммерчески доступных реагентов и компактного полуавтоматического анализатора RX Monza (Randox Laboratories LTD., Великобритания) по методике, описанной производителем. Биуретовый метод является наиболее широко используемым колориметрическим методом для определения общей конщентрации белка в сыворотке крови из-за его простоты и точности. Показатели каждого образиа измеряли в двух экземплярах. Результаты выражаются в виде среднего значения $\pm S . E$. М. Все переменные были проверены на нормальное распределение с помощью критерия Холмогорова-Смирнова $(P>0,05)$. Для выявления достоверных различий (уровень значимости, $P<0,05)$ между данными в покое и после физической нагрузки применялся знаковый ранговый критерий Вилконсона. Все статистические анализы проводились с использованием программного обеспечения STATISTICA 8.0 (StatSoft, Краков, Польша).

Уровень общего белка в крови лошадей показал незначительное повышение (на 7,1\%, P>0,05) сразу после физической нагрузки по сравнению с периодом покоя. Кроме того, уровень альбумина и глобулина в крови лошадей после тренировок был незначительно повышен на 5,9\% (p>0,05) и 8,1\% (p>0,05). Достоверных различий в соотношении сывороточный альбумин/حлобулин между периодом по-

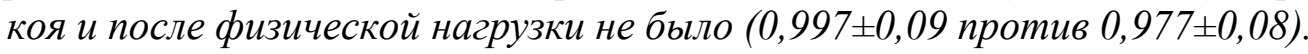

Результаты нашего исследования показали, что физические нагрузки оказывают статистически незначимое влияние на содержание общих белков и их фракций в сыворотке крови лошадей. Фракции и соотнотение альбумины//лобулины находились в пределах значений, полученных у лошадей другими исследователями. Таким образом, установлено, что общий белок и его фракции увеличивались у лошадей после тренировки, и это увеличение было незначительным, хотя и имело прямую корреляцию с физическими нагрузками. В данной работе показано, что тренировка может изменять физиологию и влиять на биохимию гематобиохимических показателей крови у лошадей, подвергнутых физическим нагрузкам.

Ключевые слова: лошади, рекреационная верховая езда, Поморский регион (Польша), тренинг, общий белок, белковые фракции, альбумины, глобулины, отношение альбумина к глобулину (AGR)

ЗМІНИ РІВНЯ ЗАГАЛЬНОГО БІЛКА ТА ЙОГО ФРАКЦІЙ У КРОВІ КОНЕЙ, ЩО ВИКОРИСТОВУЮТЬСЯ У РЕКРЕАЦІЙНІЙ ВЕРХОВІЙ ЇЗДІ, ВИКЛИКАНІ ФІЗИЧНИМ ТРЕНІНГОМ

Ткаченко Г. М., Кургалюк Н. М., Інститут біологї та наук про Землю, Поморська Академія в Слупську, Польщза

Ткачова I. В., Інститут тваринництва, Національна академія сільськогосподарських наук Украӥни, Харків, Украӥна 
Метою изього дослідження був аналіз рівня загального білка і його фракцій в крові коней, що беруть участь у рекреаційній верховій їзді (Поморське воєводство, північна Польща). У изьому дослідженні використовували 13 здорових дорослих коней из Поморского региона Польши (деревня Стшелинко, N54³048,0 E16 5744,9$)$ у вічі 9,5 $\pm 2,4$ року, в тому числі 5 - гуиульської породи, 2 - чистокровної верхової, 2 - англо-арабської $і 4$ коня невизначеної породи. Всі коні брали участь у рекреачійній їзді. Тренування тривало 1 годину і складалося з кроку (5 хвилин), рисі (15 хвилин), кроку (10 хвилин), рисі (10 хвилин), кроку (5 хвилин), галопу (5 хв) і кроку (10 хв). Зразки крові відбирали з яремних вен тварин вранці, через 90 хвилин після годівлі, коли коні перебували в стайні (між 8:30 і 10 годинами ранку), і відразу після тренування (між 11:00 і 2:00 вечора). Для отримання сироватки кров збирали в прості пробірки без антикоагулянтів. Кров зберігали в пробірках з К3-ЕДТА і витримували на льоду до центрифугування при 3000 g протягом 15 хвилин. Плазма була видалена. Загальний білок і його фракиії вимірювали при температурі $+23^{\circ} \mathrm{c}$ біуретовим методом з використанням комериійно доступних реагентів $i$ компактного напівавтоматичного аналізатора rx Mопza (Randox Laboratories LTD., Великобританія) за методикою, описаною виробником. Біуретовий метод є найбільш широко використовуваним колориметричним методом для визначення загальної концентрачії білка в сироватщі крові через його простоту і точність. Показники кожного зразка вимірювали у двох примірниках. Результати виражаються у вигляді середнього значення \pm S. E. М. всі змінні були перевірені на нормальний розподіл за допомогою критерію ХолмогороваСмирнова (p>0,05). Для виявлення достовірних відмінностей (рівень значущості, $p<0,05)$ між даними в спокої $i$ після фізичного навантаження застосовувався знаковий ранговий критерій Вілконсона. Всі статистичні аналізи проводилися 3 використанням програмного забезпечення STATISTICA 8.0 (StatSoft, Kраків, Польщча).

Рівень загального білка в крові коней показав незначне підвищення (на $7,1 \%, p>0,05)$ відразу після фізичного навантаження в порівнянні з періодом спокою. Крім того, рівень альбуміну і глобуліну в крові коней після тренувань був незначно підвищений на 5,9\% $(p>0,05)$ i 8,1\% $(p>0,05)$. Достовірних відмінностей y співвідношенні сироватковий альбумін / глобулін між періодом спокою і після фі-

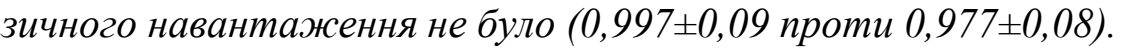

Результати нашого дослідження показали, щзо фізичні навантаження мають статистично незначний вплив на вміст загальних білків та їх фракцій у сироватці крові коней. Фракиії і співвідношення альбуміни / глобуліни знаходилися в межах значень, отриманих у коней іншими дослідниками. Таким чином, встановлено, щзо загальний білок $і$ його фракиії збільшувалися у коней після тренування, $i$ це збільшення було незначним, хоча і мало пряму кореляцію з фізичними навантаженнями. У даній роботі показано, щзо тренування може змінювати фізіологію і впливати на біохімію гематобіохімічних показників крові у коней, підданих фізичним навантаженням.

Ключові слова: коні, рекреаційна верхова їзд, Поморський регіон (Польщза), тренінг, загальний білок, білкові фракиії, альбуміни, глобуліни, відномення альбуміну до глобуліну (AGR) 